\title{
Improve the Ability to Learn to Read Early by Using SAS Methods
}

\author{
Kustianah \\ SDN Limbangan 03 \\ kustianah90@gmail.com
}

\section{Article History}

received 3/12/2020

revised $17 / 12 / 2020$

accepted 31/12/2020

\begin{abstract}
Bahasa Indonesia is one of the fields of study taught in elementary schools, in the framework of coaching and passion and development of the age of elementary school children, the skills of Bahasa Indonesia are often an obstacle for students in terms of reading and writing. The purpose of the study, knowing the improvement of early reading skills using the Synthetic Analytics Structural (SAS) method. This type of research is Class Action Research using cycle models. The researchers showed that in the initial condition, the average reading skills of students were 67.71 with a classical completion rate of $42.85 \%$. In cycle I, the average reading skills of students was 68.42 with a classical completion rate of $57.14 \%$. In cycle II, the average student score was 76.71 with a classical completion rate of $85.71 \%$. From the whole cycle that has been done, it can be concluded that the teacher has been able to improve the reading skills of the beginning of Grade I students by using the method of stuktural analytics sintatik. Each cycle always has a positive impact towards improving the development of early reading ability of Grade I students
\end{abstract}

Keywords: SAS method, early reading learning, elementary school.

\begin{abstract}
Abstrak
Bahasa Indonesia merupakan salah satu bidang studi yang diajarkan di sekolah dasar, dalam rangka pembinaan dan penghayatan serta pengembangan usia anak sekolah dasar, maka keterampilan Bahasa Indonesia sering menjadi kendala bagi siswa yaitu dalam hal membaca dan menulis. Tujuan penelitian, mengetahui peningkatan ketrampilan membaca permulaan dengan menggunakan metode Struktural Analitik Sintetik (SAS). Jenis penelitian adalah Penelitian Tindakan Kelas dengan menggunakan model siklus. Hasil Penelitia menunjukan bahwa pada kondisi awal, nilai rerata keterampilan membaca siswa 67.71 dengan tingkat ketuntasan klasikal 42,85\%. Pada siklus I, nilai rerata keterampilan membaca siswa 68,42 dengan tingkat ketuntasan klasikal 57,14 \%. Pada siklus II, nilai rerata siswa 76,71 dengan tingkat ketuntasan secara klasikal 85,71\%. Dari keseluruhan siklus yang telah dilakukan,dapat disimpulkan bahwa guru telah mampu meningkatkan keterampilan membaca permulaan siswa Kelas I dengan menggunakan metode stuktural analitik sintatik. Setiap siklus selalu membawa dampak yang positif ke arah peningkatan perkembangan kemampuan membaca permulaan siswa Kelas I
\end{abstract}

Kata kunci: metode SAS, pembelajaran membaca permulaan, sekolah dasar

Social, Humanities, and Education Studies (SHEs): Conference Series https://jurnal.uns.ac.id/shes 


\section{PENDAHULUAN}

Mata Pelajaran Bahasa Indonesia merupakan salah satu bidang studi yang diajarkan disekolah dasar, dalam rangka pembinaan dan penghayatan serta pengembangan usia anak sekolah dasar, maka keterampilan Bahasa Indonesia sering menjadi kendala bagi siswa yaitu dalam hal membaca dan menulis. Kaitannya dalam hal menulis dan membaca sangat erat, sehingga tidak dapat dipisahkan. Pada waktu guru mengajarkan menulis kata atau kalimat, siswa tentu akan membaca kata atau kalimat tersebut. Kemampuan membaca diajarkan sejak dini.

Membaca permulaan adalah tahapan awal atau dasar dalam membaca dimana bisa dilatihkan dari tingkat huruf, suku kata, dan kata yang masih sangat sederhana dan dengan cara yang menyenangkan.

Supriyadi (1992: 133) berpendapat bahwa pembelajaran membaca di Sekolah Dasar bisa dikategorikan dalam dua bagian antara lain membaca permulaan dan membaca lanjutan. Membaca permulaan diajarkan ditahap kelas I dan II yang mana pada prosesnya mengutamakan pada ketrampilan segi mekanisnya.

Melalui pembelajaran tersebut diharapkan peserta didik dapat mengenal huruf, suku kata, kata serta kalimat. Darmiyati Zuchri dan Budi Asih ( $2007: 71$ ) berpendapat bahwa kemampuan yang diajarkan dikelas I dan II merupakan kemapuan tahap awal atau tahap permulaan. Oleh karena itu pembelajaran membaca di kelas I dan II disebut pembelajaran membaca permulaan.

Menurut H.G. Tarigan (2008:7) mendefinisikan pengertian membaca adalah sebagai suatu proses yang dilakukan serta dipergunakan oleh pembaca untuk memperoleh pesan yang hendak disampaikan oleh penulis melalui media kata-kata atau bahasa tulis. Membaca mencakup membaca merupakan suatu proses, membaca adalah strategi, membaca merupakan interaktif.

Menurut Saleh Abbas (2006:101) membaca pada hakikatnya adalah suatu aktivitas untuk menangkap informasi bacaan baik yang tersurat maupun yang tersirat dalam bentuk pemahaman bacaan secara literal, inferensial, evaluative dan kreatif dengan memanfaatkan pengalaman pembaca. Hal ini juga disebutkan oleh Farida Rahim (2005:1) terdapat tiga istilah yang sering digunakan untuk memberikan komponen dasar dari proses membaca yaitu recording, decoding dan meaning. Menurut Lerner (Rini Utami Aziz, 2006: 15), kemampuan membaca merupakan dasar untuk menguasai berbagai bidang studi. Jika anak pada usia permulaan sekolah tidak segera memiliki kemampuan membaca, ia akan mengalami kesulitan dalam mempelajari bidang studi lain. Menurut Iskandar Wassid dan Dadang Sunendar (2008: 289) tujuan pembelajaran membaca dibagi menjadi tingkat pemula, menengah, dan mahir.

Kemampuan membaca akan berbeda-beda pada setiap anak dan berkembang sesuai dengan stimulus yang diberikan. Akan tetapi ada beberapa faktor yang dapat mempengaruhi kemampuan membaca pada anak (Farida Rahim, 2005: 16), seperti; factor fisiologis, factor intelektual, factor lingkungan,factor social ekonomi anak,factor psikologis. Agar dapat menumbuhkan keterampilan berbahasa anak khusus keterampilan membaca diusia anak kelas I pada jenjang pendidikan dasar diperlukan metode pembelajaran bahasa secara khusus. Salah satu metode pembelajaran bahasa Indonesia yang dapat dikembangkan untuk meningkatkan keterampilan membaca pada anak sekolah dasar adalah metode SAS (Struktural Analitik Sintetik). Berdasarkan permasalah diatas, guru mencari penyebab kurangnya respon terhadap materi pembelajaran sehingga dapat dirumuskan beberapa masalah antara lain :

a. Apakah Metode SAS dapat mengatasi kesulitan belajar menulis permulaan?

b. Bagaimana usaha untuk mengatasi masalah kesulitan belajar menulis permulaan pada siswa kelas I? 
Adapun tujuan dari penelitian ini, secara umum, untuk mengetahui penggunaan metode Struktural Analitik Sintetik (SAS) dapat meningkatkan keterampilan membaca permulaan pada siswa kelas ISD.

\section{METODE}

Penelitian ini dilaksanakan di kelas I SDN Limbangan 03 Kecamatan Kersana Kabupaten Brebes pada bulan Maret sampai April 2019. Model Pembelajaran yaitu menggunakan SAS (Struktural Analitik Sintetik) merupakan pembelajaran membaca permulaan dengan menggunakan proses penguraian kalimat menjadi kata, suku kata menjadi huruf, kemudian dilanjutkan dengan proses sistesis ( Mulyati dan Cahyani : 2017). Menurut Oktaviani dkk (2014) metode SAS adalah metode membaca keseluruhan baru ke bagian yaitu anak dilatih menguraikan kata-kata dari sebuah kalimat, kata,suku kata. Menurut Alfin (2008) langkah-langkah membaca permulaan menggunakan metode SAS yaitu membaca permulaan tanpa buku yaitu dengan cara merekam bahasa siswa, membaca gambar dengan kartu kalimat.

Metode penelitian yang dimanfaatkan untuk pengumpulan data dalam Penelitian Tindakan Kelas adalah wawancara, observasi dan tes lisan. Dalam penelitian tindakan kelas ini, teknik analisis data yang digunakan adalah teknik deskriptif. Data yang dianalisis berupa rata-rata dan prosentase hasil belajar siswa. Data yang diperoleh disajikan dalam bentuk tabel. Untuk mengetahui keberhasilan Penelitian Tindakan Kelas ini, penulis menetapkan indikator kinerja: Rata-rata $75 \%$ siswa sudah aktif. Penelitian ini dilaksanakan dengan dua siklus. Penelitian tindakan kelas ini dibagi menjadi empat tahapan meliputi perencanaan,pelaksanaan,observasi dan refleksi.

\section{HASIL DAN PEMBAHASAN}

Penelitian tindakan kelas yang dialaksanakan pada kelas I SD Negeri Limbangan 03, Kecamatan Kersana Kab.Brebes tahun pelajaran 2018/2019, dilakukan secara kolaboratif artinya, antara peneliti dan guru berpartisipasi aktif dan bekerja sama dalam penelitian. Peneliti melaksanakan sistem saling mengisi dan memberi masukan demi penyempurnaan kegiatan.

Meskipun kegiatan tersebut bersifat kolaborasi SAS, tetapi peneliti tidak membebani guru untuk proses penetuan instrumennya, karena semua dilaksanakan oleh peneliti. Guru diharapkan menglola proses pembelajaran sampai melakukan tindakan berkelanjutan secar periodik. Selanjutnya untuk mengetahui keberhasilan penelitian ini dapat dilihat pada kegiatan peserta didik dan guru selama kegiatan pembelajaran, dan disini disebutkan adanya peningkatan dalam proses pembelajaran.

Pengembangan pembelajaran sudah baik karena sudah menggunakan media pembelajaran yaitu kartu huruf dan dalam proses pembelajaran sudah menggunakan penerapan metode SAS yang sesuai untuk memacu peserta didik aktif dalam membaca. Kreatifitas peserta didik dalam pembelajaran sudah baik, dimana semua peserta didik sudah ikut berperan aktif dalam pembelajaran. Peserta didik juga sudah berani menjawab pertanyaan guru, serta sudah ada peserta didik yang berani dalam mengemukakan pertanyaan apabila belum memahami materi.

Pada akhir pembelajaran guru mengadakan pos tes yaitu dengan memberi pertanyaan yang harus dikerjakan oleh peserta didik. Dan hasil dari tes tersebut mengalami peningkatan. Dalam pembahasan ini penulis memaparkan secara garis besar hasil dari kegiatan perbaikan pembelajaran pada siklus I dan pada siklus II. Sebelum penelitian hasil tes membaca di kelas I SDN Limbangan 03 dari 35 peserta didik 20 peserta didik mendapatkan hasil yang kurang maksimal sehingga peneliti mengadakan perbaikan. Setelah perbaikan pembelajaran dilaksanakan kemudian dilakukan tes. Berdasarkan tes tersebut diperoleh data dan tingkat penguasan peserta didik terhadap materi membaca permulaan pada mata pelajaran Bahasa Indonesia kelas I SD N Limbangan 03. Data tersebut dinyatakan dalam bentuk nilai / prestasi belajar siswa dalam mata pelajaran Bahasa Indonesia. 
SHEs: Conference Series 3 (4) (2020) $152-157$

Tabel 1. Rata-rata dan Prosentase Hasil Belajar Kelas I SDN Limbangan 03

\begin{tabular}{cccc}
\hline Nilai & Jumlah siswa (awal) & $\begin{array}{c}\text { Jumlah } \\
\text { siswa(siklus I) }\end{array}$ & $\begin{array}{c}\text { Jumlah siswa } \\
\text { (siklus II) }\end{array}$ \\
\hline$>65$ & 15 & 20 & 30 \\
$<65$ & 20 & 15 & 5 \\
Rata-rata & 67,71 & 68,42 & 76,71 \\
Prosentase & $42,85 \%$ & $57,15 \%$ & $85,71 \%$ \\
\hline
\end{tabular}

Table 1 menunjukan prosentase hasil belajar peserta didik kelas I SDN Limbangan 03. Hasilnya menunjukan bahwa peserta didik yang memperoleh nilai kurang dari KKM 65 sebanyak 20 peserta didik atau 42,85\% dari total keseluruhan peserta didik. Sedangkan peserta didik yang nilainya telah mencapai KKM sebanyak 15 peserta didik atau $57.15 \%$ dari total keseluruhan peserta didik. Untuk peningkatan jumlah peserta didik yang tuntas dalam belajar diberikan tindakan perbaikkan pada siklus I. Dari kondisi awal ke siklus I mengalami peningkatan ketuntasan belajar yaitu dari $42,85 \%$ menjadi 57,15 \%. Selain ketuntasan rata-rata hasil belajar juga mengalami peningkatan dari 67,71 menjadi 68,42. Pada siklus I ini ketuntasan belajar baru mencapai $57,15 \%$ berarti peningkatan tersebut belum mencapai kriteria yang diharapkan yaitu $75 \%$ dari total jumlah siswa. Selanjutnya pada siklus II peserta didik yang mendapatkan nilai ketuntasan yaitu sebanyak 30 peserta didik dari 35 peserta didik atau $85,71 \%$.

Perolehan hasil belajar peserta didik pada siklus I sudah menunjukan adanya peningkatan dengan ketuntasan klasikal sebanyak $57,15 \%$ dan perolehan nilai ratarata 68,42 . Hal ini menunjukan bahwa penelitian tindakan kelas pada siklus I belum berhasil. Kendala yang dihadapi dalam pembelajaran siklus I yaitu guru masih banyak menggunakan metode ceramah, peserta didik belum memahami metode SAS, pada saat pembelajaran didominasi oleh siswa yang pandai sehingga peserta didik yang kurang hanya diam, dan keterbatasan alat peraga sehingga pada saat pembelajaran peserta didik saling berebutan. Penelitian dilanjutkan ke siklus II dengan memperbaiki dan lebih mengoptimalkan pembelajaran sesuai dengan hasil refleksi. Perbaikan itu diantaranya guru lebih memberikan bimbingan kepada peserta didik selama kegiatan pembelajaran, peserta didik lebih diarahkan untuk memperhatikan temannya pada saat melakukan presentasi dan memberikan komentar terhadap hasil presentasi tersebut, dan guru juga memberikan hadiah atau reward kepada peserta didik yang menjawab dengan benar baik secara individu ataupun kelompok, mengurangi metode ceramah, menambah alat peraga, dan memberikan motivasi terutama pada peserta didik yang lemah.

Dari pengamatan terhadap proses pembelajaran yang terjadi pada tindakan siklus II, peserta didik menjadi lebih aktif, kreatif dan partisipatif. Semua kelompok ratarata sudah aktif hanya satu, dua yang kurang tetapi sudah mendapat perhatian khusus untuk diberikan motivasi. Sehingga lebih baik dari siklus I. Peserta didik sudah lebih paham dalam mengikuti langkah-langkah pembelajaran membaca permulaan model SAS. Karena pengalaman dari siklus I peserta didik telah mengenal cara memahami makna kalimat maka peserta didik dapat memecahkan masalah secara lancar. Dan hampir semua peserta didik dapat lebih paham. Peserta didik yang aktif sudah merata. Kerjasama antar peserta didik juga sudah terlihat dalam diskusi berpasangan dan pada saat mempresentasikan hasil kerjanya. Dalam membahas tugas guru telah mengurangi metode ceramah sehingga peserta didik bisa mandiri aktif dan memanfaatkan waktu dengan baik. Hasil ketuntasan yang dicapai pada siklus II yaitu 85,71 \%. Dapat dikatakan bahwa peserta didik sudah mencapai ketuntasan belajar karena telah memenuhi standard ketuntasan belajar yaitu $75-80 \%$. 
Hasil penelitian tindakan kelas ini juga sejalan dengan penelitian yang telah dilaksanakan oleh Nurti Dwiyanti di SDN Saradan I. Nurti Dwiyanti (2009 : 39 ) menyatakan bahwa "Pendekatan metode SAS dalam proses pembelajaran Bahasa Indonesia dapat meningkatkan hasil belajar peserta didik. Hal ini didukung dengan hasil penilaian yang mencapai diatas KKM. Pada siklus II observasi peneliti telah mengalami perubahan dan mencapai taraf prosentase yang tinggi. Berdasarkan hasil penelitian dengan menggunakan metode SAS (Struktural Analitik Sintetik) hasil belajar peserta didik pada mata pelajaran Bahasa Indonesia materi menulis permulaan di kelas II SDN Saradan 1 meningkat dan berhasil". Berdasarkan pada hasil penelitian yang dilakukan peneliti dalam menerapkan metode SAS dalam pembelajaran membaca permulaan di kelas I SDN Limbangan 03 menunjukan bahwa dengan menerapkan metode SAS mampu meningkatkan hasil belajar peserta didik di kelas I SDN Limbangan 03 pada mata pelajaran Bahasa Indonesia semester II tahun Pelajaran 2018/2019. Hal ini menjadi persamaaan dalam penelitian ini dengan penelitian sebelumnya adalah dilaksanakannya penelitian dengan menerapkan metode pembelajaran SAS pada mata pelajaran Bahasa Indonesia. Penelitian yang telah dilaksanakan oleh Nurti Dwiyanti menunjukan keberhasilan melalui penerapan metode SAS dapat meningkatkan hasil belajar peserta didik. Hal yang menjadi pembeda dalam penelitian tindakan kelas yang dilaksanakan oleh penulis dengan penelitian terdahulu adalah materi yang digunakan pada penelitian terdahulu adalah menulis permulaan sedangkan materi yang disampaikan peneliti adalah membaca permulaan..

\section{SIMPULAN}

Berdasarkan pada pembahasan dalam Penelitian Tindakan Kelas (PTK) ini, maka dapat disimpulkan sebagai berikut :

1. Pengunaan Metode SAS Dalam Menangani Kesulitan Belajar Membaca Permulaan Mata Pelajaran Bahasa Indonesia peserta didik Kelas I SDN Limbangan 03 Tahun Pelajaran 2018/2019 dapat meningkatkan keaktifan dan kreatifitas peserta didik secara maksimal dalam pembelajaran.

2. Pendekatan Metode SAS dalam proses pembelajaran Bahasa Indonesia dapat meningkatkan hasil belajar. Hal ini didukung dengan hasil penilaian yang mencapai diatas KKM

Implikasi praktis yang diperoleh dari pelaksanaan penelitian tindakan kelas ini adalah sebagai berikut:

1. Sekolah dapat menambah koleksi perpustakaan dan menyediakan referensi tentang PTK.

2. Peneliti memperoleh pengalaman dalam menerapkan dan mengembangkan pembelajaran dengan metode SAS dalam mata pelajaran Bahasa Indonesia.

3. Siswa dapat belajar secara aktif, kreatif dan menyenangkan serta dapat meningkatkan kemampuan membaca.

\section{DAFTAR PUSTAKA}

Alfin, Jauharoti. (2008). Bahasa Indonesia. Jakarta: LAPIS

Darmiyati, Zuchdi \& Budi Asih. (2007) Pendidikan Bahasa dan Sastra Indonesia di kelas rendah. Yogyakarta

Dwiyanti, Nurti. (2009). Penggunaan Metode SAS Dapat Meningkatkan Kesulitan Belajar Menulis Permulaaan Mata Pelajaran Bahasa Indonesia Siswa Kelas II SDN SARADAN 1. PTK Mahasiswa S1 PGSD UNS 2009/2010

H.G.Tarigan. (2008). Membaca sebagai suatu ketrampilan berbahasa. Bandung: Angkasa

Iskandar Wassid dan D.Sunendar. (2008). Strategi Pembelajaran Bahasa. Bandung: Rosdakarya 
Lerner (Rini Utami Aziz. (2006). Jangan Biarkan Anak Kita Berkesulitan Belajar. Solo : Tiga Serangkai

Mulyati,Yeti dan Cahyani,Isah. (2017). Ketrampilan Berbahasa Indonesia SD. Tangerang Selatan. Universitas Terbuka

Oktaviani,Rina,dkk. (2014). Anak Islam Gemar Membaca. Jakarta : Eska kids

Rahim, Farida. (2005). Pengajaran Membaca di Sekolah Dasar. Padang : Bumi Aksara

Saleh Abbas. (2006). Pembelajaran Bahasa Indonesia Yang Efektif Di Sekolah Dasar. Jakarta: Depdikbud

Soejono (Lestary). (2004) Perbedaan Efektifitas Metode Lembaga Kata dengan Alat bantu gambar dan tanpa gambar 